TEME, г. XLI, бр. 2, април - јун 2017, стр. 391-406

Прегледни рад

DOI: 10.22190/TEME1702391D

Примљено: 15. 5. 2016.

UDK 316.774:659.1

Ревидирана верзија: 17. 10. 2016.

Одобрено за штампу: 15. 6. 2017.

\title{
БОДРИЈАРОВО ВИЪЕЊЕ УЛОГЕ МАСОВНИХ МЕДИЈА У САВРЕМЕНОМ ДРУШТВУ
}

\author{
Ђорђе Ђорђевић \\ Ниш, Србија \\ djordjesoc35@gmail.com
}

\begin{abstract}
Апстракт
Жан Бодријар спада у оне ауторе који привлаче пажњу теоретичара. Готово да нема уџбеника социолошких теорија у којем нису поменуте и његове кључне идеје. Без обзира на све контроверзе у вези са његовим делом, Бодријар представља незаобилазног аутора код сваког разматрања постмодернистичког дискурса у науци. Он је истовремено инспирисао и многе уметнике тако да су и тоталитарни дистопијски светови креирани у имагинацији стваралаца у оквиру седме уметности данас најчешће описивани као бодријаровски светови. Када је реч о масовним медијима, у Бодријаровим делима је посебно значајан термин симулакрум. Према Бодријару, сви првобитни културни облици се апсорбују у говору рекламе. Бодријар опажа тенденцију ка некој врсти владавине рекламе као форме изражавања, чак и онда када није реч о номиналној реклами. Његово специфично виђење савремених средстава масовног комуницирања чини га једним од кључних теоретичара медијске културе.
\end{abstract}

Кључне речи: Жан Бодријар, симулакрум, виртуелна реалност, масовни медији, социјалне дистопије.

\section{BAUDRILLARD'S VIEW OF THE ROLE OF THE MASS MEDIA WITHIN THE CONTEMPORARY SOCIETY}

\begin{abstract}
Jean Baudrillard is one of the authors that constantly attract the attention of theoreticians. There are hardly any sociology textbooks which do not discuss his key ideas. In spite of all the controversy around his work, Baudrillard is an unavoidable author in any discussion on the postmodern discourse in sciences. At the same time he has inspired many artists, resulting in the fact that many film artists have created totalitarian dystopian worlds which have commonly been referred to as Baudrillard's worlds. When it comes to the mass media, Baudrillard's works emphasize the term simulacrum. According to Baudrillard, all original cultural forms are absorbed in commercial discourse. Baudrillard notices a tendency of the commercial to become a supreme form of expression, even when it does
\end{abstract}


not come to a nominal commercial. His specific view of the modern means of mass communication has made him one of the key theoreticians of the media culture.

Key words: Jean Baudrillard, simulacrum, virtual reality, mass media, social dystopias.

\section{УВОД}

Када се говори о постмодерним теоријама о савременом друштву, најчешће се наводи име Жана Бодријара (Jean Baudrillard). Он свакако спада у авангардне мислиоце друге половине XX века о којима тек са ове временске дистанце можемо у потпуности објективно да судимо. За његово име и дело везују се различите оцене. Према некима од њих, Бодријар је „најрадикалнији теоретичар постмодернизма, који у исто време има професионално образовање социолога" (Mitrović, 2003, стр. 203). У сличном тону говоре и Мајкл Хараламбос (Michael Haralambos) и Мартин Холборн (Martin Holborn) када кажу како се његови ставови сматрају најекстремнијим од свих осталих постмодернистичких виђења света (Haralambos - Holborn, 2002, стр. 639). Бодријарова склоност ка артизму и поигравању властитим идејама свакако је утицала на то како ће критичари перципирати његово дело. Поред свих оспоравања његових идеја, већина аутора заступа мишљење да Жан Бодријар представља незаобилазног теоретичара код било ког озбиљнијег разматрања савремених социолошких теорија.

Данас готово да нема значајнијег уџбеника социологије који не би макар у једном свом делу садржао и одељак о теоријама Жана Бодријара и његовом несвакидашњем виђењу савременог друштва. Ентони Гиденс (Anthony Giddens) наглашава значај овог француског аутора, те сматра да је он ,један од најутицајнијих савремених теоретичара медија" (Gidens, 1998, стр. 243). Бодријар свакако јесте инокосна личност чије дело изазива бројне контроверзе, али истовремено и привлачи пажњу различитих теоретичара. Футуристички усмерен поглед Бодријарове оптике чини га писцем који је и данас у потпуности актуелан.

Његово виђење савременог света наводи се у бројним научним радовима, али његово дело можда се још чешће употребљава и у ненаучне сврхе - у новинарски поједностављеним чланцима, нарученим памфлетима, али и у дневно-политичким расправама. Учестало је и површно коришћење његовог термина симулакрум зарад интелектуалне разметљивости и збуњивања саговорника који не познаје његово значење, као ни саме Бодријарове списе. ${ }^{1}$ Бодријар је због

${ }^{1}$ Симулакрум је као термин коришћен и у делима осталих постмодерниста. Поред осталих, о њему је писао и Фредерик Џејмсон (Frederic Jameson). Термин 
свог стила писања и провокативности властитих идеја један од оних аутора који су привукли пажњу шире јавности, а не само научних кругова. Његове идеје постају незаобилазно интелектуално „оружје” многих јавних расправа у којима се тежи ка победи - али и ка откривању истине у свету премреженом масовним медијима и њиховим (све)моћним утицајем.

Сам аутор поседује снажно изражену склоност ка генерализацијама. Његове теорије су конципиране тако да покушавају имати опште важење за сва друштва данашњице, као и за светско друштво у целини. Истовремено, он примере којима поткрепљује своје тезе углавном наводи из свакодневног живота развијених друштава Запада, пре свега ЕУ и САД. Када говори о „нестајању реалности”, „клонираној реалности”, „симулакруму”, „виртуелној реалности” и осталим кључним терминима који се помињу у његовим делима, аутор истовремено прећуткује ко су одговорни за такво „плагирање реалности" у друштву. Иако је некада у младости Бодријар био марксиста, чини се да је у својим каснијим делима из неког разлога бежао од директног указивања на кривце за „убиство реалности” о којем пише, тако да има оних критичара који управо у томе виде једну од главних слабости његовог дела. Многи Бодријара доживљавају не као класичног научника, већ као неку врсту песимистичног пророка будуће технолошке дистопије.

\section{СПЕЦИФИЧНОСТ БОДРИЈАРОВОГ ПРИСТУПА САГЛЕДАВАНУ ДРУШТВА}

Мешање различитих жанрова и поигравање идејама иначе је један од начина испољавања креативности у делима постмодерниста. Попут осталих постмодерниста, Бодријар такође пише стилом који је на граници између науке и литерарног. Бодријарова дела одликују се и поетским излетима, бројним метафорама, недовољно појашњеним тврдњама, различитим ставовима у различитим делима, као и различитим тврдњама и унутар једног истог дела (а понегде чак и унутар једне мало дуже реченице), појединачним примерима из живота који уместо илустрације служе доказивању ауторових тврдњи и изузетно слободних генерализација. Приликом било које анализе Бодријарових главних идејних поставки, незаобилазно се појављује проблем недовољне разумљивости његових списа.

постмодернизам у Америци је ушао у ширу употребу почетком седамдесетих година XX века. Према Јелени Ђорђевић, постмодернизам није само филозофија, тип културе, нити уметнички стил, већ представља и специфичан поглед на свет, који није без идеолошких и политичких набоја и контроверзи (Đorđević, 2009, стр. 183). 
Чини се да је то уједно једна од главних критика које му упућују други аутори када у својим радовима дају приказе његових главних идеја. Поред тога, оптужују га и за недореченост и скакање са идеје на идеју. Између осталог, поједини критичари га у вези са његовом идејом да је моћ потпуно нестала и да политика више није реална оптужују за „честу контрадикторност”, као и за то да су његове тврдње толико „екстремне да их је тешко доказати. Он не нуди никакву дефиницију моћи, па је тешко проценити његову тврдњу да је нестала" (Haralambos - Holborn, 2002, стр. 640).

Бодријарово инсистирање на властитим екстремним ставовима упркос доказима које нуди реалност често је иритирало остале теоретичаре. Највише критика је изазвао његов чланак непосредно пре избијања Заливског рата 1991. године, насловљен „Рат у Заливу се не може десити". Ентони Гиденс о томе каже:

„Кад је рат објављен и кад су крвави сукоби почели, чинило се да аутор није био у праву. Ни најмање. Кад се рат завршио, он је написао други чланак - 'Рат у Заливу се није десио'” (Gidens, 1998, стр. 243).

Није изненађујуће то што многи Бодријарове идеје виде као неку врсту ексцентричности у науци. Претераност у ставовима овог аутора највише штети њему самом и његовом делу, она чини то да и реални елементи његовог учења бивају скупа са њом одбачени. Тачно је да исувише радикални ставови аутора у вези са појединим питањима истовремено привлаче пажњу публике и изазивају бурне полемике, али и реакција у виду потпуног одбацивања аутора и његових идеја јесте пратећа последица пажње која је привучена на такав „инстант” начин. У вези са претходнонаведеним случајем Хараламбос и Холборн такође неповољно оцењују Бодријарове тврдње да је Рат у Заливу био само низ слика које су створили медији. Такво Бодријарово стајалиште, према њима, показује „помањкање везе са стварношћу, јер постоје безбројни свједоци тих догађаја" (Haralambos - Holborn, 2002, стр. 1073).

Идеја о Бодријаровом „помањкању везе са стварношћу” може бити узета као једно од објашњења, али нама се чини да је пре реч о једној врсти намерно смишљеног екстремизма ставова који има за циљ да својом ексклузивношћу привуче пажњу јавности на самог аутора и његово дело. Такви ставови (укључујући и онај о томе да реалног више нема) засигурно јесу претерани, али су управо тиме обезбедили свом аутору место у свим уџбеницима социологије. Сам Бодријар у својим делима на више места истиче да он намерно до крајњих граница заоштрава своје ставове, поиграва се идејама и кључне идеје намерно донекле замагљује не би ли их тако спасао од оних који мисле да све знају и њихове површне критике, али тиме истовремено изазива и бес оних којима измиче могућност схватања његовог дела. Бодријар о томе каже: 
„Обично се каже да глупост вређа, али права увреда је објашњење. (...) С онима који схватају, закључујем уговор о интелигенцији, а с осталима, у исто време, склапам кришом пакт о глупости" (Bodrijar, 1997, стр. 153).

Недовољна разумљивост често се од стране читалаца тумачи као доказ генијалности аутора. Бодријарови списи, како тврди он сам, донекле „беже” од потпуног разумевања читаоца и тиме га истовремено ,заводе”. Поред наведених чињеница, ваља истаћи и то да Бодријарова дела нису писана у виду научних радова намењених социолозима или политиколозима. Без обзира на своје професионално образовање, Бодријар у својим делима иступа пре као филозоф (а не социолог), тако да и онда када говори као социјални филозоф његове идеје нису у форми строгих дефиниција које би биле погодне да се на основу њих створи целовит и детаљан теоријски концепт, већ имају облик личних опажања и слободних генерализација, без неког нарочитог залагања аутора да те своје ставове поткрепи неким квантитативним подацима. Чак и када наводи неке случајеве из социјалног живота, Бодријар поприлично вешто узима као доказ исправности сопствених генерализација управо оно што би евентуално требало да послужи само као илустрација његових идеја. Његов стил писања више је налик књижевном изразу, без навођења било какве литературе.

\section{КОНЦЕПТ СИМУЛАКРУМА}

Одредити „симулакрум” једном једином дефиницијом није нимало лак задатак - како због већ наведеног проблема дешифровања Бодријарових основних теоријских поставки тако и због идеолошкопропагандне злоупотребе његовог имена и дела у политичким расправама и свакодневним журналистичким поједностављивањима његових идеја. Напокон, ни сам аутор у својим делима не даје неку строгу дефиницију симулакрума, већ читаоца полако, путем прикладних поређења и примера, уводи у разумевање своје концепције. Други проблем приликом одређивања симулакрума јесте у Бодријаровој склоности ка исувише описним одређењима, али проблем подједнако представља и извесна недоследност на којој му замерају готово сви критичари, те најзад и проблем ауторове донекле измењене првобитне концепције симулакрума у каснијим делима.

Да би читаоцима својих књига на што једноставнији начин објаснио шта је то симулакрум, Бодријар се у многим делима на самом почетку као помоћним средством користи причом о иконоборцима у Византији, која има своје упориште у стварној историји. Реч је о сукобу између иконобранилаца и иконобораца изазваном декретом цара Лава III Исавријског из 726. године о забрани обожавања 
светих слика. Поменути сукоб се завршио тек 843. Године, када је Синод у Константинопољу донео одлуку о слободи поштовања икона (Милосављевић, 2002, стр. 40). Бодријар у књизи Савршен злочин о том историјском догађају каже:

„Византијски иконопоклоници били су истанчани људи који су сматрали да представљају Бога да би увеличали његову славу, а заправо су, симулирајући Бога у сликама, прикривали проблем његове егзистенције. Иза сваке од тих слика, Бог је нестао. Није био мртав, већ је нестао. А то значи да се сам проблем више није постављао. Био је решен симулацијом. Ми то чинимо с проблемом истине или реалности овог света: решили смо га техничким симулирањем и умножавањем слика у којима више нема шта да се види" (Bodrijar, 1998, стр. 15).

Под светлом такве спознајне оптике, Бодријар указује и на неке од примера симулакрума у нашој савремености. Њима иманентно својство представља покушај да се постојање добра докаже преко постојања зла као његове супротности у сфери етичког, односно да се постојање реалног докаже путем приказивања лажног - односно фалсификата реалног. Слично томе, уметност се доказује постојањем антиуметности, педагогија се доказује антипедагогијом. На трагу истог размишљања, аутор у свом другом делу ( $O$ завођењу) каже да се може живети само са идејом о кривотвореној истини:

„То је једини начин да се живи истина. Све друго је неподношљиво (управо зато што истина не постоји). Не треба уклањати појаве (заводљивост слике). Тај подухват треба осујетити да не би плануло одсуство истине. Или одсуство Бога. Одсуство Револуције. Револуција једино може живети од идеје да јој је све супротстављено, а пре свега њен мајмунски, пародични двојник: стаљинизам. Стаљинизам је бесмртан јер ће увек бити ту да сакрије да Револуција, истинита Револуција не постоји, и да тако подгрева наду" (Бодријар, 1994, стр. 65).

Преусмеравањем пажње ка копији, егзистенција оригинала више није спорна. Перцепција, а и критика онда су преусмерене ка фалсификату (евентуално и ка фалсификаторима), али и ка питањима у вези са тим да ли је реч о доброј (успелој) или лошој (неуверљивој) копији. Питање реалности оригинала не само да престаје да буде предмет пажње већ се уопште ни не поставља. Симулакрум је самим тим и један вид преусмеравања пажње. Према Бодријаровом учењу, најсажетије одређење симулакрума било би оно које каже да је он фалсификована слика непостојећег оригинала. ${ }^{2}$

\footnotetext{
${ }^{2}$ Бодријар избегава директне дефиниције, али на једном месту каже: „симулакрум није оно штто скрива истину, већ оно што скрива одсуство истине" (Bodrijar, 2009, стр. 19).
} 
Слично томе, Бодријар у Дизниленду не види само забавни парк, већ „доказ” да је све остало, све оно изван њега, заиста реално - а да је само он измишљени непостојећи свет. Према овоме, могло би се помислити да је у Бодријаровој концепцији једина функција симулакрума та да прикрива одсуство било какве реалности. На неким местима Бодријар ту функцију изричито подвлачи као једину, те стога има оних истраживача Бодријаровог дела који симулакрум схватају само под светлом те функције.

\section{ДВЕ ФУНКЦИЈЕ СИМУЛАКРУМА}

Бодријар нигде не говори директно строгим социолошким језиком о свим функцијама симулакрума, али је из његових дела ономе ко их истражује могуће издвојити макар две кључне функције. Према првој, о којој је већ било речи, симулакрум који је од реципијената схваћен као (исувише очигледно препознатљива) „лажна слика" праве реалности/истине служи да би се прикрило да те реалности заправо нема. Очигледна (или лоша) копија нечега прикрива питање непостојање оригинала.

Друга функција симулакрума је његово коришћење у рекламне сврхе - а то се постиже путем конструисања виртуелне реалности која се меша са стварним светом. Примера ради, према Бодријару и сам Лос Анђелес је имагинаран, главни задатак његових житеља, њихова обавеза и одговорност је у томе да непрекидно показују како су срећни и насмејани да би се створио привид да макар негде постоји савршен живот. Према Бодријару, тај град није само центар холивудске фабрике снова, већ је и он сам (скупа са својим увек насмејаним житељима) једна велика реклама за American way of life. Нека врста живог билборда, рекламна слика овоземаљског раја која буди наду и даје обећање савршеног живота и савршене забаве. „Америка није ни сан, ни реалност. То је хиперреалност" (Bodrijar, 1993, стр. 30).

Као што је већ наведено, Бодријарова мисао је у приличној мери поетска и метафорична, тако да он често скаче са идеје на идеју у оквиру једног рада. Зарад прецизности, морамо додатно објаснити ове две функције симулакрума. Наиме, Бодријар нигде не покушава да међусобно упореди ове две функције, али се на основу његових ставова могу извести и учења о двема врстама симулакрума. Први, који према Жану Бодријару служи као „пародија реалности” (зарад доказивања уз помоћ њега да она постоји), отворено је лажан и људи су свесни његове лажности. Људско реаговање на њега је праћено ставом: Ако је ово копија (својеврсни фалсификат) реалности, онда мора да постоји и кривотворени оригинал (реалност).

Други симулакрум је такође копија реалности, али он од стране реципијената није схваћен као копија, већ се доживљава као реал- 
ност. Ова условно речено друга врста симулакрума служи као битан конститутивни елемент виртуелне реалности - о чему Бодријар говори у својим каснијим делима насталим у позним годинама. Поучен критикама које су уследиле, али и подстакнут развојем саме технологије стварања виртуелне реалности, он је током деведесетих макар донекле ревидирао своје ставове, те самим тим и одређење симулакрума са којим је иступао током претходних година. Речју, он сада не тврди да реалности/стварности нема у потпуности, већ да она истовремено коегзистира са виртуелном реалношћу, уз тенденцију потпуне доминације ове друге:

\begin{abstract}
„Некада су то двоје били повезани живахним кретањем неке повести: из виртуелног се помаљала актуелна форма, као статуа из комада мермера. Данас се они преплићу у чувеном кретању мртваца - мртвац наставља да се креће, а леш реалног непрестано расте. Виртуелно је, уосталом, само ширење мртвог тела реалног - умножавање довршеног универзума, којем преостаје једино да се хиперреализује у бескрај. Налазимо се у убрзаној фази тог кретања, где су све 'реалне' ствари сабијене, да ту живе и умру” (Bodrijar, 1998, стр. 59).
\end{abstract}

Другим речима, реално није у потпуности нестало - али показује тенденцију растварања у мору виртуелне реалности. Промена Бодријарове концепције је очигледна, делимично као плод самих напада критичара, ауторове зрелости, али и вишег степена уверљивости његових идеја у друштву обележеном експанзијом компјутерске технологије која непрекидно напредује. То само сведочи да је Бодријар као и сви генијални људи ишао знатно испред свог времена. Раних осамдесетих било је поприлично тешко замислити реално као неку врсту компјутерски клонираног виртуелног света који је испрограмиран и чији становници верују да заиста живе у реалном свету.

Оно што може бити занимљиво социјалном теоретичару јесте својеврсно капитулирање аутора пред популарном верзијом његове теорије која постоји у јавности. Донекле ревидирана Бодријарова теорија истовремено се приближава тумачењима која је посматрају под светлом критике манипулације у савременом друштву која се спроводи пре свега путем масовних медија. Идеја да реалности више нема може у оквиру социологије изгледати интригантно због своје оригиналности, али чини се да су социолози, барем у већини, заинтересованији да иначе еластичну Бодријарову мисао тумаче преко медијске манипулације масама.

Чињеница је да су прогресивно усмерени интелектуалци пословично осетљиви на сва она питања која се тичу могућности да неке отуђене снаге у друштву путем манипулације преузму потпуну контролу над њим. Стога су социолози у Бодријаровом делу заинтересованији за питање злоупотребе виртуелне реалности, а мање за 
саме ауторове филозофско-поетске излете и необичне језичке обрте. Они Бодријарове идеје „читају” у кључу медијске манипулације и опасности формирања неке хиперконтролисане технолошке дистопије у будућности. ${ }^{3}$

\section{СИМУЛАКРУМ И МАСОВНИ МЕДИЈИ}

Претходно је већ истакнуто да је кључна функција симулакрума прикривање да реалности заправо нема. Реалност се замењује стварањем лажне (виртуелне) реалности. У том процесу стварања виртуелне реалности централну улогу имају масовни медији. Бодријар ни на једном месту не говори дуже у континуитету о улози масовних медија, али се унутар његових списа могу извући фрагменти чијим се спајањем може сагледати целовита слика о ауторовом виђењу њихове улоге. Бодријар истиче да живимо у свету у коме је највиша функција знака, медија и уметности брисање реалности и у исто време прикривање њеног нестанка (Bodrijar, 1998, стр. 16). Према аутору, сви првобитни културни облици апсорбују се у говору рекламе, који је без дубине и представља тријумф површног облика и нултог степена смисла. Бодријар опажа тенденцију ка некој врсти владавине рекламе као форме изражавања.

Чак и када није реч о номиналној реклами (дакле, оној која се производи у те сврхе), у свим формама активности користи се рекламни облик - заправо оне преузимају облик рекламе. У друштву виртуелне реалности долази до стапања „свих виртуелних начина изражавања у начину оглашавања, у начину рекламе” (Bodrijar, 1991, стр. 91). Бодријар рекламну форму изражавања идеја препознаје и у политици у којој све постаје политички маркетинг. У таквом друштву реклама постаје водећи културни модел, чиме се брише разлика између политичког и економског. Језик политике и језик економије постају један исти језик - језик рекламе у друштву у коме се све посматра као конкурентска утакмица на тржишту. Политичке идеје, политичке странке и сами политичари постају ништа више од робне марке (Bodrijar, 1991, стр. 92).

Док с једне стране политичари своје говоре подређују рекламном облику изражавања, с друге стране се ствара квазикомуникациона ситуација у којој се политичке елите позивају на вољу народа односно јавног мњења. Док су се традиционални монарси позивали на божју вољу као извор своје власти и моћи, дотле савремени поли-

\footnotetext{
${ }^{3}$ Постоји више могућих начина „читања” Бодријаровог дела. Даглас Келнер (Douglas Kellner) указује и на то да се Бодријарова „футуристичка постмодернистичка друштвена теорија може читати и као научна фантастика" (Kelner, 2004, стр. 493).
} 
тичари на питање у вези са тим ко их је овластио одговарају да их је овластио управо онај ко пита - апстрактно јавно мњење. Жан Бодријар стога каже:

„Тај симулакрум инверзије или инволуције полова, то генијално лукавство које је тајна целог дискурса манипулације и према томе, данас, тајна сваке нове власти у уклањању са сцене власти, у уклањању свих говора из којих је произашла та фантастична ћутљива већина, карактеристика нашег доба - све је то, без сумње, започело у политичкој сфери са демократским симулакрумом" (Bodrijar, 1991, стр. 162).

Поред политичких реклама и такозваних озбиљних програма који се баве друштвено значајним питањима, и остале медијске форме такође пружају могућност конструисања симулакрума. Медијска слика постаје копија реалности, да би након тога реалност постала копија медијског симулакрума. Масе су збуњене таквим преливањем из виртуелног у реално и обрнуто, те не успевају да разликују где престаје граница између ових двеју сфера. Овакве Бодријарове идеје могу изгледати тешко доказиве, али он најчешће наводи речит пример популарне америчке телевизијске серије „Кафић у здравље” („Cheers”). Ентеријер виртуелног кафића у ситкому био је копија реалног изгледа сличних места, дакле, копија реалности - да би након успеха серије широм Западних земаља почели да се отварају на аеродромима и аутобуским станицама кафићи истог имена, као физички верне копије телевизијског кафеа из серије. На тај начин је првобитни телевизијски симулакрум из америчке серије добио свој симулакрум. Виртуелни и никад постојећи „Кафић у здравље” пресликао се у физичку реалност земаља Запада.

Слично је и са популарним телевизијским сапуницама. Творци телевизијских серија попут „Династије”/,Dynasty” и „Даласа”/,Dallas” покушавали су да и реалне животе глумаца који у њима учествују подреде потребама живота и смрти ликова које они у тим серијама играју. Глумице које учествују у овим серијама присиљене су од стране продукције да сниме сцену смрти у базену. Ако им се нешто догоди у реалности, медијска кућа ће тим сценама оправдати њихов нестанак из серије (Bodrijar, 1997, стр. 76). Сличан пример мешања реалног и медијских слика који Бодријар наводи јесте и случај америчке породице Лауд (Loud) из Санта Барбаре. Она је пристала на то да једна телевизијска станица током извесног времена снима све њене активности. Епилог је био тај да се поменута породица распала. Тај за то време необични програм представљао је неку врсту претходнице савремених тзв. ријалити шоу-програма. 


\section{НЕСТАНАК РЕАЛНОГ}

Медијска слика која настоји да реално прикаже стварност често користи и проблематичне методе разарања саме стварности. Бодријар наводи пример Кополиног (Coppola) филма „Апокалипса данас” / „Apocalypse Now” (1979, Francis Ford Coppola), у коме су зарад критике рата у Вијетнаму и пластичног приказивања окрутних поступака америчке војске током снимања филма заиста напалм бомбама уништена села и хектари шума на Филипинима. Како би се дочарао ужас рата у Јужном Вијетнаму, злочин је поновљен, али овог пута не зарад ратног освајања, већ зарад Кополине мегаломанске жеље да створи филм који би био реалнији од реалности - и то уз звуке Вагнерове музике за време спаљивања филипинских села (Bodrijar, 1991, стр. 60-61).

Жан Бодријар у свим производима медијске продукције препознаје „клонирање реалности”. Телевизијски пренос концерта на ком се свира Моцартова композиција или њено репродуковање на јапанској електроници по његовом мишљењу је такође нека врста симулакрума јер та композиција није написана за такву врсту извођења. Слично томе, говорећи о масовним медијима, Бодријар наводи да се порнографија обично оптужује на два начина - или као сексуално манипулисање у корист неутрализовања класне борбе, или као комерцијално изопачавање секса. Насупрот томе, он сматра да порнографија служи као симулакрум, дакле, она маскира да правог секса нема. Задржавањем на детаљима и „микроскопским увећањем” појединих делова тела, порнографија као и сваки симулакрум тежи да буде реалнија од саме реалности, али она само прикрива да реалности нема (Бодријар, 1994, стр. 67).

Чини се да оваква разноврсна Бодријарова опажања очигледних симулакрума из свакодневног социјалног живота чине ону чињеничку основу његових погледа коју је тешко оборити. Жан Бодриjap је указао на постојање медијских симулакрума, али су истовремено и остали истраживачи током времена почели да поткрепљују његове концепције о мешању реалног и виртуелног новим доказима. Обично се као речит доказ наводи познати случај из британске телевизијске продукције. Британски телевизијски гледаоци масовно су писали управи лондонске полиције са захтевом да се из затвора пусти глумица која је у серији невино оптужена (Haralambos - Holborn, 2002, стр. 16). Забрињавајуће је то што више од десет хиљада људи који су полицију засули писмима са захтевом за ослобађање телевизијског лика очигледно нису били у стању да разликују реално од медијске слике.

Претходно је под светлом Бодријарових идеја већ сагледан однос средстава масовног комуницирања и симулакрума. Ако смо спознали каква је по Бодријару улога масовних медија у савременом 
свету, намеће се и питање ко стоји иза њих и производње симулакрума. Речју, које друштвене снаге стоје иза стварања виртуелне реалности у савременом друштву. У вези са овим питањем ваља рећи да Бодријар говори о манипулативној улози медија, али избегава да укаже ко су појединци или друштвене групе које стоје иза њих. Бодријарово учење није социјално ангажована критика и указивање на могуће правце друштвених промена зарад превазилажења постојећег стања. ${ }^{4}$ Његова књига Савриен злочин тако је названа због тога што писац сматра да је за „убиство реалности” немогуће пронаћи кривце:

„Последице овог злочина су вечите зато што ту нема ни убице ни жртве. Да постоји бар једно од то двоје, тајна злочина би била кад-тад откривена, а злочиначки процес разрешен” (Bodrijar, 1998, стр. 9).

Он унапред полази од те претпоставке и чак ни не покушава да попут многих критички ангажованих мислилаца „кривце” пронађе у редовима политичке елите или међу власницима капитала који у својим рукама поседују средства масовног комуницирања. Он говори само о једном процесу уништења реалног, а починиоце не наводи јер према његовом концепту то није ни могуће. Његово виђење савременог друштва је нескривено песимистично, али он не нуди могућа решења као излаз из те ситуације. Без обзира на своја марксистичка убеђења из младости, Бодријар у својим зрелим годинама не наступа као заступних тих идеја, чак ни онда када се чини да његова размишљања о друштвеној стварности иду у том правцу:

„У срцу нашег универзума знакова, налази се Лукави Дух рекламе, trickster, који је ујединио лакрдију трговине и њену режију. Неки генијални сценариста (сам капитал?) повукао је свет у фантазмагорију чије смо сви очаране жртве" (Bodrijar, 1998, стр. 87).

Одбијајући да се директно изјасни, Бодријар пружа могућност читаоцу његових списа да сам пронађе кривца у редовима оних друштвених група које сматра одговорним за формирање виртуелне реалности. Приликом сагледавања Бодријарових идеја може доћи до различитих тумачења од стране различитих аутора. Његово дело отуда често подсећа на познати „Роршахов тест” са мастилом.

\footnotetext{
${ }^{4}$ Тодор Куљић подсећа да је за постмодерну вера у бољу алтернативну будућност празноверица, док прогрес представља превазиђен појам (Kuljić, 2006, стр. 94).
} 


\section{УМЕСТО ЗАКљУЧКА: \\ БОДРИЈАРОВЕ СОЦИЈАЛНО-ДИСТОПИЈСКЕ ИДЕЈЕ}

Многи Бодријара посматрају као песимистичног пророка будуће технолошке дистопије. Са ове временске дистанце можемо говорити о Бодријаровој доброј способности да јасно наслути поједине тенденције у будућности. Када је Бодријар осамдесетих година XX века доводио у питање постојање реалности, то је у том тренутку могло да делује као мисаоно поигравање са већ познатим идејама источњачке филозофије која овај свет види као неку врсту сна или обмане. Без обзира на то што има оних који у Бодријаровим идејама препознају само техницизирани ехо некадашњих учења источњачке филозофије, његова опажања о виртуелној реалности назначена много пре њене техничке реализације носе снажан печат аутентичности аутора.

Другим речима, невезано за то да ли су неке идеје Истока евентуално надахнуле Бодријарова филозофска разматрања, треба му одати признање за то што је на вешт и интелектуално провокативан начин повезао источњачку филозофију, дотадашње социолошке критике потрошачког друштва и масовне културе, скупа са елементима мрачних дистопија попут оних код аутора као што су Џорџ Орвел (George Orwell), Олдос Хаксли (Aldous Huxley), Реј Бредбери (Ray Bradbury) и други. Колики је значај филозофских разматрања Жана Бодријара сведочи и то што су у свим каснијим дистопијама (или негативним утопијама) коришћени многи елементи које је први назначио управо творац идеје о нестанку реалности. Дистопије су познате у друштвеним наукама, али подједнако и у свету уметности. Негативно-утопијски призори тоталитарних и техницизираних друштава, настали у оквиру како седме тако и девете уметности, јесу омаж Жану Бодријару.

Почетна иницијатива припада Бодријару као „икони постмодерне мисли” (Maširević, 2011, стр. 101), али идеје многих аутора коje је инспирисао иду даље самостално у другим правцима. Свеједно, тоталитарни светови које уметници стварају добијају ту част да у критичким приказима њихових дела понесу назив „бодријаровски светови”. Филмови „Труманов шоу” / „The Truman Show” (1998, Peter Weir), „Град таме” / „Dark City” (1998, Alex Proyas), као и „Матрикс” / „The Matrix” (1999, Laurence/Lana Wachowski; Andrew Paul Wachowski) и његова два наставка представљају препознатљиве примере таквих бодријаровских светова. Теоретичари попут Дагласа Келнера препознају немерљив Бодријаров утицај и када је реч о савременом сајберпанку (Kelner, 2004, стр. 491).

Жан Бодријар свакако није писац социјалних дистопија, али су у његовим делима јасно присутни елементи социјално-дистопијских размишљања. Свет виртуелне реалности бодријаровског типа јесте једна тоталитарна творевина на трагу ранијих негативних утопија у 
литератури, али тај свет је утолико страшнији што из њега нема бекства и могућности побуне, јер по Бодријару нема ни кривца против кога би се ваљало борити. Бодријар изричито одбија да пронађе одговорне. На једном месту он каже: „Медији собом носе смисао и противсмисао, манипулишући истовремено у свим правцима, нико не може да контролише тај процес" (Bodrijar, 1991, стр. 88).

Бодријаров постмодернистички скептицизам је приметан у његовим делима, невезано за то што аутор одбија било какво самоодређење или пак етикету коју би му други наметнули, па чак и то да се изјасни као постмодерниста. Постмодерна мисао одбацује све „велике приче", тако да се Бодријар задовољава само тиме да преузме улогу хроничара са рушевина реалности. Појединим ауторима сметају управо тај Бодријаров скептицизам према променама и цинизам према реалности. Његов нихилизам је најизраженији у делима насталим после осамдесетих година XX века. У њима, према мишљењу Дагласа Келнера, Бодријар потпуно блазирано напросто „осликава спектакл отуђеног европског интелектуалца који посматра колапс модернизма и хладно и иронично га бележи у својим текстовима" (Kelner, 2004, стр. 522).

Жан Бодријар се несумњиво сматра једним од најзначајнијих и свакако незаобилазних теоретичара када је реч о анализирању савременог друштва и улоге масовних медија у њему. Он је један од пионира указивања на опасност стварања виртуелне реалности и његова футуристичка промишљања представљају добру основу при сагледавању актуелне садашњице. Значај Жана Бодријара је и у популаризовању једног погодног термина - симулакрум. Без обзира на то што он на појединим местима изричито негира да спада у „теоретичаре манипулације”, његово истраживање симулакрума га de facto убраја у ту групу. Другим речима, само стварање симулакрума јесте једна врста манипулације, без обзира на то што нико конкретно (према Бодријару) од тога неће имати користи.

Сваки симулакрум као фалсификована слика непостојећег оригинала чини конститутивну јединицу која заједно са осталим симулакрумима формира виртуелну реалност у којој се мешају материјална реалност и медијски продуковане слике. Она права „истинска реалност", која по Бодријару све више нестаје, бива клонирана, те тако добијамо клонирану реалност (или хиперреалност), која настоји да буде „реалнија од саме реалности”. Међусобна испреплетеност медијских слика и истинске реалности доводи до тога да се не само реалност пресликано клонира на хиперреалистичан начин у медије већ и до тога да се из медија симулакруми пресликавају на физичку реалност. Без обзира на све контроверзе, Бодријар је успео да намерно заоштреним екстремизмом ставова изазове интересовање за своје несвакидашње идеје. Његово место у сваком уџбенику социолошких теорија данас је у потпуности потврђено. 


\title{
ЛИТЕРАТУРА
}

Bodrijar, Ž. (1991). Simulakrumi i simulacija [Simulacra and Simulation]. Novi Sad: IP Svetovi.

Bodrijar, Ž. (1993). Amerika [America]. Beograd: Buddy Books.

Бодријар, Ж. (1994). О завођењу [Seduction]. Подгорица: Октоих.

Bodrijar, Ž. (1997). Cool memories [Cool Memories]. Vršac: Književna opština Vršac.

Bodrijar, Ž. (1998). Savršen zločin [The Perfect Crime]. Beograd: Časopis Beogradski krug.

Bodrijar, Ž. (2009). Pakt o lucidnosti ili inteligencija zla [The Intelligence of Evil or the Lucidity Pact]. Beograd: Arhipelag.

Đorđević, J. (2009). Postkultura: uvod u studije kulture [Subculture: An Introduction to Cultural Studies]. Beograd: Clio.

Gidens, E. (1998). Sociologija [Sociology]. Podgorica: CID.

Haralambos, M. - Holborn, M. (2002). Sociologija. Teme i perspektive [Sociology: Themes and Perspectives]. Zagreb: Golden Marketing.

Kelner, D. (2004). Medijska kultura: studije kulture, identitet i politika između modernizma i postmodernizma [Media Culture: Cultural Studies, Identity, and Politics Between Modern and the Postmodern]. Beograd: Clio.

Kuljić, T. (2006). Kultura sećanja: teorijska objašnjenja upotrebe prošlosti [Memory Culture: Theoretical Explanation of the Use of the Past]. Beograd: Čigoja.

Maširević, Lj. (2011). Postmoderna teorija i film na primeru kinematografije Kventina Tarantina [Postmodern Theory and Film Exemplified in Quentin Tarantino's Cinema]. Beograd: Čigoja.

Милосављевић, Љ. (2002). Средњовековна мисао о друштву [Social Theories in the Middle Ages]. Ниш: Филозофски факултет.

Mitrović, Lj. (2003). Opšta sociologija - predmet, teorije i savremeno društvo [General Sociology - Subject, Theories and Modern Society]. Beograd: Institut za političke studije.

\section{BAUDRILLARD'S VIEW OF THE ROLE OF THE MASS MEDIA WITHIN THE CONTEMPORARY SOCIETY}

\author{
Đorđe Đorđević \\ Niš, Serbia
}

\section{Summary}

Jean Baudrillard is one of the avant-garde philosophers whose work attracts the attention of both scientists and a wider public. Baudrillard's specific view of the modern means of mass communication has made him one of the key theoreticians of the media culture. His controversial ideas of the simulacrum, disappearance of the real, virtual reality and „murder of reality" have made him an unavoidable "icon of postmodern thought" in opinion of many theoreticians.

When it comes to the mass media, Baudrillard's works emphasize the term simulacrum. Baudrillard himself often uses the parable about iconoclasts who forbade worship of icons and thus neglected the questions on the existence of God. By redirecting the attention to the copy, the existence of the original is not to be questioned any more. 
Considering Baudrillard's works, the most concise definition of the simulacrum is the one that claims that it is a faked image of the non-existing original.

Baudrillard never uses a directly strict sociological terminology about all the functions of the simulacrum, but those who study his work may extract at least two main functions. According to the first, the simulacrum that is perceived by the recepients as an all too obvious "faked image" of the actual reality/truth serves the purpose of covering the fact that the mentioned reality in fact does not exist. The second function of the simulacrum as a socio-cultural phenomenon is its use for commercial purposes. This is achieved by constructing a virtual reality which is mixed with the real world by its recepients.

Mutual overlapping of media images and the actual reality not only results in the reality being cloned onto the media in a hyper-realistic way, but also in the simulacra from the media being cloned onto the physical reality. Baudrillard supports these overlappings with wordy examples, such as the popular American TV series Cheers, TV soap operas Dynasty and Dallas, as well as the film Apocalypse Now (1979, Francis Ford Coppola). The mentioned examples provide a mixture of the media-produced images and the actual "real reality" while the media simulacra attain their copies in the reality.

In his works, Jean Baudrillard does not provide any lengthy discussion on the role of the mass media in the contemporary society. However, an analysis of his writings can emphasize the fragments which, if combined, may provide a thorough image of the author's view of their role. According to Baudrillard, all original cultural forms are absorbed in the commercial discourse. Baudrillard notices a tendency of the commercial to become a supreme form of expression, even when it does not come to a nominal commercial.

Many authors perceive Jean Baudrillard not as a classic scientist, but as some kind of a pessimistic prophet of the future technological dystopia. Baudrillard was an avantgarde philosopher in many respects. Baudrillard's individual views of the contemporary society and the role of the mass media within it have inspired many artists. The significance of the philosophical observations made by Jean Baudrillard is supported by the fact that many subsequent dystopias (or negative dystopias) used many elements originally specified by the creator of the idea of the disappearance of reality. Hence the name "Baudrillard's worlds" for all dystopian worlds created in the works of artists. The negatively utopian scenes of totalitarian and technisized societies created within the seventh and ninth art are a homage to Jean Baudrillard as one of the most radical theoreticians of postmodernism. 